\title{
MarTin Ološtiak
}

\section{Cudzie propriá v slovenčine z pohl’adu teórie motivácie $v$ lexikálnej zásobe*}

K l’úč ové slová: lexikálna zásoba, lexikológia, lexikálna motivácia, cudzie propriá

\section{1. Úvodné poznámky}

J. Furdík rozpracoval koncepciu, ktorá predstavuje jeden z možných celkových prístupov k skúmaniu lexikálnej zásoby. V tejto koncepcii sa lexika považuje za súbor lexikálnych jednotiek (jednoslovných a viacslovných), ktoré sú späté sietami rôznych vzt’ahov. Klúčovým pojmom a termínom v tomto prístupe je lexikálna motivácia, ktorá sa pokladá za základný princíp fungovania lexiky vo všetkých jej aspektoch. Vychádza sa z týchto teorém: (a) lexéma je neizolovaná jednotka (porov. existenciu rozličných lexikálnoparadigmatických vztahov, napr. synonymia, antonymia, homonymia, paronymia); (b) pri skúmaní lexiky sa preferuje onomaziologický prístup (od obsahu k forme), ktorý odráža prirodzený smer semiózy; (c) lexikálna motivácia poskytuje jednak možnost' odpovedat' na otázku Prečo sa lexéma $\mathbf{X}$ volá tak?, jednak tu ide o vlastnost' ako siet' vzt’ahov medzi lexikálnymi jed-

* Táto práca vznikla v rámci riešenia projektu VEGA č. 1/0102/09 Elektronické spracovanie anglických vlastných mien $v$ slovenčine. 
notkami. Autor svoj prístup formuluje v opozícii k F. de Saussurovi takto: „Nie arbitrárnost', ale motivovanost' jazykového znaku je absolútna” (Furdík 2000: 59; podrobnejšie a súhrnne porov. Furdík 2008: 27-33).

Lexikálna motivácia je strechovým pojmom/termínom, v konkrétnej analýze sa počíta s viacerými, presnejšie so sedemnástimi motivačnými typmi. Typológia a hierarchizácia jednotlivých typov bola pri konštituovaní tejto teórie pre J. Furdíka jednou z klúčových otázok, ku ktorej sa neustále vracal (Ološtiak 2008: 12-16). V poslednom variante sa dopracoval k tejto hierarchizácii:

1. Základné typy: 1.1 elementárna - paradigmatická motivácia; 1.2 špecifikované: 1.2.1 zvuková; 1.2.2 sémantická; 1.2.3 morfologická; 1.2.4 slovotvorná; 1.2.5 syntaktická; 1.2.6 frazeologická; 1.2.7 onymická. 2. Nadstavbové (pragmatické) typy: 2.1 expresívna; 2.2 stratifikačná; 2.3 terminologická; 2.4 sociolektická; 2.5 teritoriálna; 2.6 temporálna; 2.7 individualizačná.

3. Kontaktové typy: 3.1 akceptačná; 3.2 abreviačná.

V našom mierne modifikovanom prístupe zatial' počítame s takouto typologickou štruktúrou a terminologickým stvárnením: I. základné (inherentné) typy: 1.1 elementárna - paradigmatická, 1.2 špecifikované: 1.2.1 slovotvorná, 1.2.2 fónická, 1.2.3 sémantická, 1.2.4 morfologická, 1.2.5 syntaktická, 1.2.6 frazeologická, 1.2.7 onymická; II. prechodné typy: 2.1 interlingválna, 2.2 abreviačná; III. nadstavbové (adherentné) typy: 3.1 expresívna, 3.2 registrová (stratifikačná), 3.3 terminologická, 3.4 sociolektická, 3.5 temporálna, 3.6 teritoriálna, 3.7 individualizačná.

Podotýkame, že porovnanie Furdíkovej a našej typológie na tomto mieste uvádzame len ilustračne, problematika typológie a hierarchizácie lexikálnej motivácie si vyžaduje väčší priestor a výskumné nasadenie. Ozrejmenie tohto problému však predpokladá analýzu súboru iných otázok súvisiacich s fungovaním lexikálnej motivácie a jednou z nich je aj motivačná relačnost', ktorej čiastkovú pozornost’ venujeme v tejto štúdii.

\section{Motivačné vzt’ahy}

V kontexte uvažovania o lexikálnej motivácii za závažný pokladáme poznatok, že typy lexikálnej motivácie nefungujú „na vlastnú päst”, ale navzájom vstupujú do rozličných vzt’ahov. Charakteristika a vysvetlenie princípov fungovania motivačných vzt'ahov predstavuje vel'mi dôležitý, ba v istom zmysle fundamentálny aspekt teórie lexikálnej motivácie. Za najvýraznejšie „plus” akcen- 
tovania relačného aspektu vo všeobecnosti pokladáme skutočnost', že týmto spôsobom možno z jednotného teoreticko-metodologického hl'adiska charakterizovat' rozmanité lexikálne javy. Takýmto spôsobom sa v lexike dajú skúmat' jednak statické aspekty (typy a vlastnosti lexikálnych jednotiek), jednak dynamické aspekty (vznik, zmeny vlastností a zánik lexikálnych jednotiek).

Relačnost' motivačných typov sa prejavuje ako (1) motivačná kooperácia; (2) motivačná determinácia; (3) motivačná inkompatibilita. Motivačnej kooperácii sa budeme venovat' v d’alšom výklade, preto sa na tomto mieste stručne zmienime len o motivačnej determinácii a motivačnej inkompatibilite.

Podstatou motivačnej determinácie je skutočnost', že nadobudnutie jedného motivačného typu je sprevádzané obmenou, oslabením alebo zánikom iného motivačného typu; porov. napr. slovotvornú univerbizáciu typu základná škola $\rightarrow$ základka (syntaktická demotivácia + slovotvorná motivácia; zo syntakticky motivovaného viacslovného pomenovania vzniká syntakticky nemotivované jednoslovné pomenovanie pomocou slovotvornej motivácie: základ-ka). Motivačná inkompatibilita je prejavom nemožnosti simultánnej prítomnosti dvoch alebo viacerých motivačných typov v jednej lexikálnej jednotke. Z tohto pohl'adu za vztahovo inkompatibilné pokladáme napr. tieto motivačné dvojice: expresívna a terminologická motivácia (neexistuje expresívny odborný termín), frazeologická a terminologická motivácia, sociolektická a terminologická motivácia.

Relačnost' má pritom svoju statickú aj dynamickú stránku. Motivačnú kooperáciu možno charakterizovat' staticky aj dynamicky, motivačnú determináciu len dynamicky a motivačnú inkompatibilitu len staticky (porov. nasledujúcu schému).

Schéma. Dimenzie motivačnej relačnosti

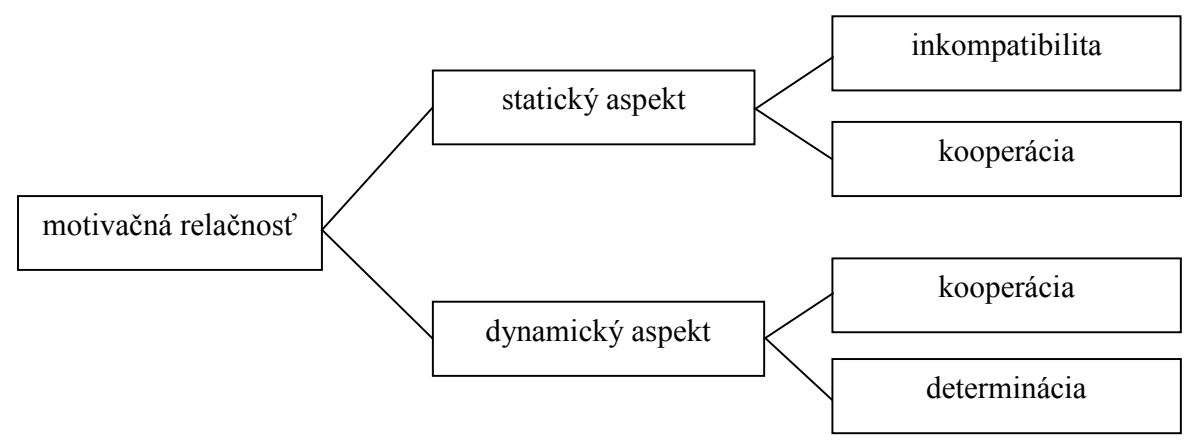




\subsection{Motivačná kooperácia}

Motivačná kooperácia sa prejavuje prítomnost'ou dvoch alebo viacerých typov motivácie $\mathrm{v}$ jednej lexéme. J. Furdík kooperačný aspekt načrtáva v štúdii Slovotvorná motivácia medzi ostatnými typmi lexikálnej motivácie (2000/2005). Poznamenáva, že: a) najmenej typov sa nachádza v lexémach z centra lexiky; b) ústrednú funkciu plní slovotvorná motivácia (stručne sa uvádzajú lexikálne javy dokumentujúce spoluprácu slovotvornej motivácie s inými typmi). Interakcia motivačných typov sa ilustruje pomocou tabul'ky; napr. trolejbus (paradigmatická + slovotvorná + kontaktová motivácia), $S D L^{\prime}$ $k a$ (paradigmatická + morfologická + slovotvorná + onymická + sociálnostratifikačná + abreviačná), antiglobalizačný (paradigmatická + slovotvorná + temporálna + kontaktová); Furdík (2005: 396).

Ako bolo spomenuté, motivačná kooperácia má statický aj dynamický aspekt. Statický aspekt sa prejavuje v prítomnosti dvoch alebo viacerých motivačných typov v jednej lexéme (takéto chápanie prezentuje aj J. Furdík; porov. vyššie). Uvádzame aspoň niekol'ko príkladov:

- green: paradigmatická motivácia (napr. súvztažnost's lexémami jamkovisko, hole, birdie, putt), interlingválna motivácia (lexéma prevzatá $\mathrm{z}$ angličtiny), registrová motivácia (športový register + golfový subregister);

- ditrochej: paradigmatická motivácia (začlenenost' do príslušnej terminologickej paradigmy, najužšia spätost's pomenovaniami iných druhov stôp: trochej, daktyl, jamb, anapest a i.), terminologická motivácia (odborný termín z oblasti literárnej teórie a verzológie), slovotvorná motivácia (trochej $\rightarrow$ ditrochej), interlingválna motivácia (grécizmus);

- europarlament (paradigmatická + slovotvorná + interlingválna motivácia);

- Toruń / Toruň (paradigmatická + onymická + interlingválna motivácia).

Dynamický aspekt sa prejavuje pri utváraní lexikálnych jednotiek. $\mathrm{Na}$ rozdiel od motivačnej determinácie, ktorej podstatou je zásada „niečo za niečo" (vznik motivačného typu X sprevádza zánik motivačného typu Y), pri motivačnej kooperácii ide o simultánne nadobudnutie dvoch alebo viacerých motivačných typov. Napríklad na utvorení prezývky Tyristorka ${ }^{1}$ sa podiela-

1 Ide o neoficiálne pomenovanie železničného rušňa radu 111, ktorý slúži predovšetkým na posunovanie. 
la slovotvorná motivácia (tyristor $\rightarrow$ Tyristorka; lexéma vznikla sufixáciou) a onymická motivácia.

\subsection{Motivačné vżt'ahy a interpretácia lexikálnych podsystémov}

Nazdávame sa, že prostredníctvom motivačných vzt’ahov možno na základe jednotného metodologického rámca interpretovat' a vyčlenit' jednotlivé lexikálne skupiny (podsystémy), resp. typy lexém, a to prostredníctvom analýzy tzv. typizovanej konfigurácie motivačných typov spájajúcich sa do istých motivačných zväzkov. Ukazuje sa totiž, že isté motivačné konfigurácie sa opakujú v tom zmysle, že možno uvažovat' o celých skupinách lexikálnych jednotiek, vyznačujúcich sa rovnakým usporiadaním a vzt’ahmi v rámci motivačných zväzkov. Napríklad skupinu viacslovných proprií možno charakterizovat' prostredníctvom kooperácie onymickej a syntaktickej motivácie - onymicky motivované sú propriá, syntakticky motivované sú viacslovné lexémy (Slovenská republika, Banská Bystrica, Ladislav Chudik), skupinu prezývok možno charakterizovat’ prostredníctvom kooperácie onymickej a sociolektickej motivácie - sociolekticky motivované sú lexémy, preferenčne alebo výhradne používané v istej societe, napr. prezývky Smejo, Chválenkár (uviedli sme len tie motivačné typy, ktoré v hierarchii príslušného motivačného zväzku stoja na najvyššej úrovni).

\subsubsection{Prevzaté (cudzie) propriá v slovenčine}

Podobným spôsobom možno charakterizovat' aj skupinu prevzatých (cudzích) proprií, ktoré sa vyznačujú onymickou motiváciou (OM) a interlingválnou motiváciou (IM). Onymicky motivované sú propriá, interlingválne motivované sú lexémy prevzaté z cudzích jazykov. K nim sa môžu pridružovat' d’alšie motivačné typy, z ktorých výberovo v nasledujúcom výklade uvádzame štyri (dokladový materiál čerpáme zo Slovníka anglických vlastných mien v slovenčine; Ološtiak, Bilá, Timková 2006).

\section{a) $\mathrm{OM}+\mathrm{IM}+$ slovotvorná motivácia}

Vo vzt’ahu k slovotvornej motivácii sa do popredia dostáva otázka slovotvornej adaptácie cudzích proprií. Čiastkový adaptačný proces na slovotvornej úrovni možno pomenovat' termínom transderivácia (Furdík 1994; Ološtiak 2007: 149-162). V jej rámci možno vymedzit’ interlingválny a intra- 
lingválny aspekt. Podstatou interlingválneho aspektu je porovnanie slovotvorného statusu vo východiskovom $\left(\mathrm{L}_{1}\right)$ a v preberajúcom jazyku $\left(\mathrm{L}_{2}\right)$. $\mathrm{Z}$ tohto pohladu transderivácia apelatív najčastejšie prebieha ako strata slovotvornej motivovanosti. Cudzie propriá sa preberajú ako slovotvorne nemotivované. Ako synchrónne nemotivované ich možno chápat' už v $\mathrm{L}_{1}$ vzhl'adom na to, že po nadobudnutí propriálnosti sa prvotná motivácia lexikálnym významom apelatíva stratila: napr. Georgetown (pôvodne: George „Juraj”, town „mesto”), Cleveland (cleve „hornatý”, land „krajina, zem”), Cambridge (,most cez rieku Granta”), Cheshire (chester „,pevnost”, shire „grófstvo”), Norfolk (,severný národ”), Suffolk (,južný národ”) a pod. (Crystal 1995: 143). Z tohto dôvodu v Slovníku koreňových morfém slovenčiny (Sokolová, Ološtiak, Ivanová et al. 2005) východiskové propriá morfematicky nečleníme (okrem gramatických morfém), a to ani vtedy, ked’ ide o domáce propriá, ktoré z diachrónneho pohl'adu možno segmentovat' (napr. Bohumil- $ø$, Boleslav$\varnothing$, Bratislav- $a$ ). Vyčleňujú sa len systemizačné sufixy typu Afgan-i:stan- Kazach-stan- $\varnothing$ - Kurd-i:stan- $\varnothing$ - Pak-i:stan- $\varnothing$, Antarkt-íd- $a$ - Arkt-íd- $a$, Armén-sk- $o$ - Bavor-sk- $o$, Áz-i- $a$ - Asýr-i- $a$, Balt-ik- $\varnothing$ - Atlant-ik- $\varnothing$. Intralingválny aspekt transderivácie súvisí s integráciou lexémy do slovotvorného systému $\mathrm{L}_{2}$, teda s participáciou prevzatej lexikálnej jednotky na slovotvornom ,živote” $\mathrm{L}_{2}$. Okrem iného zahrnuje také javy, ako motivačná potencia, spájatel'nost's cudzími a domácimi slovotvornými prostriedkami, slovotvorné alternácie, trunkácie, členstvo v slovotvorných útvaroch ${ }^{2}$. Prípady typu rock $\rightarrow$ rocker, surfovat' $\rightarrow$ surfing stoja na rozhraní interlingválneho a intralingválneho aspektu transderivácie, ked’že $\mathrm{v}_{2}$ sa odrážajú isté slovotvorné javy (vzt’ahy, prvky), typické pre $\mathrm{L}_{1}$ (napr. motivačný vzt’ah rock $\rightarrow$ rocker a s tým súvisiaca slovotvorná štruktúra motivátu rocker).

Cudzie propriá sa teda do slovenského slovotvorného systému najčastejšie začleňujú vo funkcii slovotvorných motivantov, pričom pri odpovedi na otázku, aké druhy motivátov sa od nich tvoria, je potrebné vziat' do úvahy, o aký typ vlastného mena ide, teda príslušnost' od onymickej triedy a podtriedy. Od maskulínnych antroponým (priezvisk) sa systémovo tvoria tieto typy motivátov: feminatívum (Bush $\rightarrow$ Bushová), individuálne vzt'ahové adjektí-

2 V tejto súvislosti J. Fisiak (1986: 253) podčiarkuje, že systematická analýza slovotvorby prevzatých slov by nemala obsahovat' len také aspekty, ako napr. fungovanie prevzatých afixov, hybridné kompozitá, falošní priatelia, ale aj fungovanie prevzatých slov v derivačných a kompozičných slovotvorných modeloch preberajúceho jazyka. 
vum (Bush $\rightarrow$ Bushov) a príslušnostné substantívum (Bush $\rightarrow$ Bushovci). Od maskulínnych antroponým (rodných mien) sa systémovo tvorí individuálne vzt’ahové adjektívum (George $\rightarrow$ Georgeov). Od toponymických ojkoným sa systémovo tvoria tieto typy motivátov: pomenovanie osoby (etnonymum alebo obyvatel'ský názov), od ktorej sa tvorí feminatívum (Cleveland $\rightarrow$ Cleveland'an $\rightarrow$ Cleveland'anka), a vzt'ahové adjektívum (Cleveland $\rightarrow$ cleveland$s k y ́)$. Od toponymických anojkoným sa systémovo tvorí vztahové adjektívum (Shenandoah $\rightarrow$ shenandoahský). Súbor systémovo tvorených motivátov od jednotlivých typov proprií možno pomenovat' termínom základné deonymické (deantroponymické, detoponymické) slovotvorné hniezdo (Ološtiak 2007: 154-160; Ološtiak, 2008; porov. aj termín typová slovotvorná paradigma K. Buzássyovej 2001: 79). Okrem toho podl’a závažnosti onymického objektu pomenovaného daným propriom sa môžu tvorit’ aj iné typy motivátov; bližšie porov. Ološtiak (2007: 160-162).

\section{b) $\mathbf{O M}+\mathbf{I M}+$ syntaktická motivácia}

Takto motivované sú prevzaté viacslovné propriá: napr. Andre Agassi, Samuel Beckett, Nicolas Cage, Allen Ginsberg, Billy Idol, Margaret Thatcher, Edgar Allan Poe, William Makepeace Thackeray, Francis Scott Key Fitzgerald, John Ronald Reuel Tolkien; New York, Johnson City, West Kirby.

Antroponymá majú pomerne ustálenú syntaktickú štruktúru - najčastejšie v podobe rodné meno + (stredné meno/mená) + priezvisko, a to vzhl'adom na ustálenost' funkčných členov (tento termín používame podl’a V. Blanára, 1996), z ktorých najdôležitejšie v stredoeurópskom kontexte $\mathrm{v}$ rámci oficiálnej dvojmennej sústavy sú rodné meno a priezvisko. Vychádzajúc z funkčnej prominentnosti priezviska, syntaktickú štruktúru mien typu Andre Agassi možno hodnotit' takto: nekongruentný atribút (rodné meno) + substantívum (priezvisko). V tejto súvislosti sa otvára otázka syntaktickej platnosti viacslovných toponým, ktoré sa takouto priezračnou štruktúrou nevyznačujú. Z toho pramení nezvyčajnost' takýchto slovných spojení, ktorá sa prejavuje najmä tak, že formálne vztahy medzi členmi syntagmy sa nevyjadrujú, resp. nevyjadrujú sa dôsledne. Miera syntaktickej adaptovanosti je v skupine prevzatých viacslovných toponým rozličná. Ako plnohodnotne syntakticky adaptované možno hodnotit' jednotky s komponentom, ktorý bol na základe lexikálneho významu nahradený domácim ekvivalentom - spravidla kongruentným adjektívom (South Dakota $\rightarrow$ Južná Dakota, South Caro- 
lina $\rightarrow$ Južná Karolína, New Mexico $\rightarrow$ Nové Mexiko). V d’alších typoch sa syntaktický vzt’ah členov syntagiem formálne nevyjadruje, v anglických toponymách nadradený člen zvyčajne stojí na poslednom mieste, atributívna platnost' prvého, resp. predchádzajúcich členov je vo väčšej-menšej miere zretel'ná, resp. zastretá, porov. jednotky Kansas City, Jefferson City, Salt Lake City, Hyde Park, New York, New Orleans, New Jersey, New Plymouth, West Bromwich, Palm Springs, Miami Beach, Virginia Beach, Rock Island, San Francisco, San Jose, Lower Hutt, Notting Hill, Llandrindod Wells.

\section{c) $\mathrm{OM}+\mathrm{IM}+$ abreviačná motivácia}

Abreviačne motivované sú skratky, ktoré sa v skupine prevzatých proprií zväšša správajú podobne ako v domácich propriách; najčastejšie ide o iniciálové skracovanie rodného či stredného mena: G. Bush, F. Mercury, George W. Bush, William J. Clinton. Osobitnú problematiku predstavuje preberanie mien s ustáleným alebo premenlivým skratkovým komponentom (St. Louis, St. Blazey, St. Clears, Mt./Mount Everest) a preberanie skratiek názvov inštitúcií, zriedkavejšie toponým (NATO, UNESCO, UNPROFOR; USA).

\section{d) $\mathbf{O M}+\mathbf{I M}+$ fónická motivácia}

Fónická motivácia sa tradične spája s javmi spadajúcimi do sféry zvukového symbolizmu - onomatopoje, imitatíva (napr. kikirikí, béé, miau, člups). J. Furdík sa v citovanej monografii pokúsil o rozšírené chápanie tohto motivačného typu na viaceré javy súvisiace s príznakovostou na úrovni vonkajšej formy (Furdík 2008: 43). Medzi inými javmi autor spomína aj to, že vonkajšia forma môže sprostredkovane vyjadrit' prevzatost', teda interlingválnu motivovanost'. Platí to rovnako pre apelatíva, ako aj pre propriá; porov. napr. tieto javy:

- výskyt periférnych foném $d z ̌, g, f, e ́$ : James [džejms], John [džon], Agee [ejdží], Algernon [eldžrnon], Aldridge [oldridž], George [džórdž]; Gary [geri], Gibbon [gibon], Douglas [dagles], Begley [begli]; Frank [frenk], Woolford [vúlford], Wolstenscroft [vulstenkroft], Jeff [džef], Wickliff [viklif]; Eyre [ér], Astaire [estér], Andre [andré]; výskyt príznakových kombinácií foném (napr. tvrdá výslovnost' konsonantov pred prednými vokálmi: Aldington [oldinkton], Austin [óstin], Nicolas [nikolas], Cadence [kejdens], Brewster [brúster], Nelson [nelson]; 
- kombinácie vokál + postsonantické j v iniciálovej pozícii: Eileen [ajlín], Aby [ejbi], Oyster Band [ojster bend];

- slabičné konsonanty $r, l$ vo finálnej slabike: Eagles [ígls], Nigel [najdžl], Baker [bejkr], Alger [eldžr];

- konsonant $n$ vo funkcii slabičného jadra: Bacon [bejkn];

- finálne sekvencie foném -jd, -jk, -jl, -jm, -jn, -js, -jt, -jv: Cade [kejd], Drake [drejk], Abigail [ebigejl], Gayle [gejl], Fame [fejm], Macfarlane [mekferlejn], Brice [brajs], Forsyte [forsajt], Dave [dejv].

Problematika príznakovosti vonkajšej formy prevzatých proprií by si zaslúžila väčšiu pozornost' (porov. aj Sabol 1980).

Pri anglických propriách do hry vstupuje aj príznaková asymetria medzi ortografiou a výslovnostou (porov. toponymá Aylesbury [ejzberi], Belaugh [biló], Carrantuohill [kerontúel]), vo vzt’ahu k cudzím propriám všeobecne sa ako dôležité javí skúmat' špecifiku a okolnosti ortografickej adaptácie; porov. napr. v slovenčine adaptáciu pol'ských toponým: Warszawa $\rightarrow$ adaptované podl'a výslovnosti Varšava [varšava]; Kraków $\rightarrow$ adaptované na základe ortografie Krakov [krakov].

\section{Záver}

Ukazuje sa, že teória lexikálnej motivácie má potenciu opísat' a vysvetlit' všetky lexikálne javy a procesy, ku ktorým dochádza v lexike istého národného jazyka (v našom prípade slovenčiny). Toto tvrdenie možno podporit' týmito argumentmi:

- Každá lexikálna jednotka je prinajmenšom paradigmaticky motivovaná (každá lexéma sa vyznačuje aspoň minimálnym počtom vzt’ahov k iným lexikálnym jednotkám; porov. tézu o neizolovanosti);

- Prostredníctvom tejto teórie možno charakterizovat' všetky štruktúrne typy jednotiek: jednoslovné, viacslovné, monosémické, polysémické, neodvodené, odvodené, zložené, konverzné, abreviatúry a i.

- Prostredníctvom tejto teórie možno analyzovat' aj vplyv externoligválnych faktorov na fungovanie lexiky (expresivita, čas, priestor, l'udská spoločnost'); porov. najmä tieto motivačné typy: expresívna, registrová, terminologická, temporálna, teritoriálna motivácia.

- Ďalej možno charakterizovat' všetky lexikálne procesy (spôsoby obohacovania lexiky), a to prostredníctvom: a) jednoduchého priradenia moti- 
vačného typu a spôsobu tvorenia pomenovaní (napr. slovotvorná motivácia: prezident $\rightarrow$ prezidentka, interlingválna motivácia: weekend $<$ angl.> $\rightarrow$ víkend $<$ slov.>, syntaktická motivácia: stará + mama $\rightarrow$ stará mama); b) motivačnej relačnosti (analýzou vztahov medzi jednotlivými motivačnými typmi, napr. slovotvorná univerbizácia sa dá vysvetlit’ ako strata syntaktickej motivácie a nadobudnutie slovotvornej motivácie: diplomová práca $\rightarrow$ diplomovka).

- Prostredníctvom motivačnej teórie možno opísat' aj fungovanie periférnych či jednorazových lexém - okazionalizmov (koncept individualizačnej motivácie). V príspevku sme sa zamerali na čiastkovú analýzu špecifickej a periférnej skupiny lexikálnych jednotiek - cudzích proprií. Na príklade anglických proprií (išlo o exemplifikáciu pars pro toto) z aspektu motivačnej relačnosti cudzie propriá ako celok možno charakterizovat' pomocou kooperácie onymickej motivácie a interlingválnej motivácie. K nim sa môžu pridružovat' d’alšie motivačné typy, z ktorých sme si v niekol'kých poznámkach všimli slovotvornú, syntaktickú, abreviačnú a fónickú motiváciu.

\section{Bibliografia}

Blanár V., 1996, Teória vlastného mena (Status, organizácia a fungovanie v spoločenskej komunikácii), Bratislava: Veda.

BuZÁssyová K., 2001, Slovotvorné paradigmy: ich sémantická podmienenost' a určenost', w: J. Mlacek (red.), Studia Academica Slovaca 30, Bratislava: Stimul, s. $72-82$.

CRYstal D., 1995, The Cambridge Encyclopedia of English Language, Cambridge: Cambridge University Press.

FISIAK J., 1986, The word-formation of English loanwords in Polish, w: W. Viereck,

W. D. Bald (red.), English in contact with other languages. Studies in honour of Broder Carstensen on the occasion of his 60th birthday, Budapest: Akadémiai Kiádó, s. 253-263.

FuRDíK J., 1994, Integračné procesy pri lexikálnych prevzatiach, Jazykovedný časopis 45 , s. $95-102$.

FURDík J., 2000, Motywacja słowotwórcza między innymi typami motywacji leksykalnej, w: K. Kleszczowa, L. Selimski (red.), Stowotwórstwo a inne sposoby nominacji, Materiały z 4 konferencji Komisji Słowotwórstwa przy Międzynaro- 
dowym Komitecie Slawistów (Katowice 27-29 września 2000 r.), Katowice: Wydawnictwo Gnome, s. 59-62.

FuRdík J., 2005, Život so slovotvorbou a lexikológiou. Výber štúdii pri príležitosti nedožitých sedemdesiatin (red. M. Ološtiak, L. Gianitsová-Ološtiaková), Košice: Vydavatel'stvo LG.

Furdík J., 2008, Teória motivácie v lexikálnej zásobe (red. M. Ološtiak), Košice: Vydavatel'stvo LG.

Ološtiak M., 2007, Jazykovoštruktúrny a komunikačno-pragmatický status vlastného mena (adaptácia anglických proprií v slovenčine), Prešov: Filozofická fakulta Prešovskej univerzity. [Tento dokument je prístupný aj online: $<$ http://olostiak.webz.cz/Publikovane/propria_monografia_2007.pdf $>$ ].

Ološtiak M., 2008, Proprium ako slovotvorný motivant (rozšírená verzia), Slovenská reč 72, s. 321-343. [Tento dokument je prístupný aj online: $<$ http://www.juls.savba.sk/ediela/sr/2007/6/sr2007-6.pdf>].

Ološtiak M., Bilá M., Timková R., 2006, Slovník anglických vlastných mien v slovenčine, Bratislava: Kniha-spoločník.

SABOL J., 1980, Zvukové ustrojenie vlastného mena a jeho komunikačné súvislosti, w: M. Majtán (red.), Spoločenské fungovanie vlastných mien. VII. slovenská onomastická konferencia, Bratislava: Veda, s. 35-40.

Sokolová M., Ološtiak M., Ivanová M. et al., 2005, Slovník koreňových morfém slovenčiny, Prešov: Filozofická fakulta Prešovskej univerzity v Prešove.

\section{Foreign proper names and the theory of lexical motivation}

( s u m m a r y)

The paper deals with adaptation of foreign proper names (FPN) in Slovak. The issue is analysed from the viewpoint of the theory of lexical motivation (first proposed by J. Furdík). As far as FPN are concerned, two types of lexical motivation are highlighted, namely onymic motivation and interlingual motivation. Onymic motivation concerns proper nouns and interlingual motivation concerns loan-words. The paper treats the problem of co-occurrence of the above mentioned two types of motivation, and their occurrence in conjunction with other motivation types, namely word-formation motivation (word-formation adaptation of FPN), syntactic motivation (concerning multi-word expressions), phonic motivation (concerning lexemes with a marked form), abbreviation motivation (concerning abbreviations). The exemplification is based on the corpus of English proper nouns, taken from Slovník anglických vlastných mien v slovenčine (Dictionary of English Proper Names in Slovak; Ološtiak et al. 2006). 